\title{
"By women, for women, and with women": on the integration of highly qualified female refugees into the labour Markets of Berlin and Brandenburg
}

Felicitas Hillmann ${ }^{1 *}$ (1) and Burcu Toğral Koca²

* Correspondence: Felicitas. hillmann@hu-berlin.de

'Georg-Simmel-Center for Metropolitan Studies,

Humboldt-University, Unter den Linden 6, 10117 Berlin, Germany Full list of author information is available at the end of the article

\begin{abstract}
This article focuses on the labour market integration of highly qualified female refugees in cosmopolitan Berlin and smaller towns in the county of Brandenburg. Based on interviews with civil society organisations designed mainly for female refugees, universities, employees of the job agency and government administrations, the gendered pathways of stratified access of this group to the labour markets of the two areas were analysed. Special attention was given to the role of emerging intermediary actors and their powers to influence stratified access to the labour markets. As this research shows, a variety of new approaches have evolved, and a web of migrationrelated jobs to support these women has been created - with marked regional differences.
\end{abstract}

Keywords: Labour market integration, Highly-qualified female refugees, Civil society, Intermediary actors, Differential inclusion, Berlin, Brandenburg

\section{Introduction}

In Germany, the rapidly rising numbers of refugee arrivals since 2015 initially spurred a lively debate on labour market integration of refugee men, taking up the common narrative of male job-seeking individuals and accompanying women. At present, we face an altered situation in which a specialized support structure has emerged that focuses explicitly on refugee women, often in the form of pilot projects in selected German states (hereafter "Land" or "Länder"). Various programmes at federal and local levels have addressed this highly heterogeneous group, and particularly, sometimes, the small group of highly qualified women (a process, which one of our interviewees judged as "creaming", meaning "cherry-picking"). Due to the complex and constantly shifting stratified nature of access to the German labour market for refugees in general, we still miss detailed knowledge pertaining to the situation of highly qualified

(c) The Author(s). 2021 Open Access This article is licensed under a Creative Commons Attribution 4.0 International License, which permits use, sharing, adaptation, distribution and reproduction in any medium or format, as long as you give appropriate credit to the original author(s) and the source, provide a link to the Creative Commons licence, and indicate if changes were made. The images or other third party material in this article are included in the article's Creative Commons licence, unless indicated otherwise in a credit line to the material. If material is not included in the article's Creative Commons licence and your intended use is not permitted by statutory regulation or exceeds the permitted use, you will need to obtain permission directly from the copyright holder. To view a copy of this licence, visit http://creativecommons.org/licenses/by/4.0/. 
refugee women on the German labour market. ${ }^{1}$ Generally, the allocation of the refugees to the labour market is tied to the overall allocation-system in Germany, based on a rotation system that changes its criterion annually (the so-called Königsteiner Schlüssel, see also section 3).

Drawing on the conceptual framework of "civic stratification", this article addresses this research gap and highlights the dynamics of differential inclusion of highly qualified female refugees into labour markets in Germany. As recent research already points to the weak labour market integration of female refugees (see among others Worbs and Baraulina 2017; Pallmann et al. 2019; Pfeffer-Hoffmann 2018; Fendel 2019; Kalkum et al. 2019), our interest was directed towards the processes and opportunity structures that help this disadvantaged group to gain access to a rather closed labour market. We put the role of emerging intermediary actors such as members and volunteers of civil society organisations, universities, planning agencies, and municipal institutions centre stage. They seemed to determine the access to the labour market and sometimes to disrupt the parameters of the stratification. To date, academic literature has turned a blind eye to the importance of these intermediary actors for the labour market integration of highly qualified female refugees. To close this research gap, we chose to contrast two regional realities, metropole Berlin, and smaller towns in Brandenburg.

The structure of the article is as follows. After a theoretical and conceptual discussion and explanation of the methodology (section 1a and 1b), we detail the gendered numbers of refugees and the federal and Länder level policy contexts with a specific focus on the labour market integration of female refugees (section 2 and 3). Section 4 then outlines the reactions of civil society to the challenges of the labour market integration of highly qualified female refugees. Section 5 presents the findings and emphasises the reactions of intermediary actors as well as refugees themselves. The concluding section summarises the empirical findings.

\section{Theoretical and conceptual framework}

As we know from research on the gender dimension of migration, migrant women generally have a lower educational status than men and face more difficulties than men both during the migration journey and later on with their integration into the labour market of their place of arrival (Hillmann and Wastl-Walter 2011). Not only are women often attributed a lower professional status than men in the countries of origin considered here. Frequently they show a lower level of education and - even more decisive for their success in their place of arrival - they are less likely to have experienced full immersion into the formal labour markets of their places of origin. As a consequence, they are not prepared for integration into the highly formalized structure of labour markets such as that which exists in Germany where, for instance, employees tend to be asked for certified qualifications. This structural imbalance can work as an higher burden for women than for men - as many professions do not require a formal

\footnotetext{
${ }^{1}$ The authors thank the organisers of two workshops on 'Labor market integration of highly skilled refugees in Sweden, Germany and The Netherlands', Micheline van Riemsdijk and Linn Axelsson, taking place at the University of Uppsala and the Stockholm University (2019) for their generous support and the participants for their valuable comments. The research results presented here benefitted from the financial support of the Oxford-Berlin Initiative within the Berlin University Alliance (grant OXBER_SOC5) and the Einstein FellowShip programme of the Einstein Foundation Berlin (EGP-2018-489, 489-2). We also thank three anonymous reviewers for their comments.
} 
degree in the country of origin and women are even more likely to rely on informal training. In accordance with the formalized structure of the German labour market, the qualification system with its fragmented categories is hardly accessible for newcomers (Knuth 2017; Konle-Seidl 2017). In addition, the German vocational training system has, to date, not been sensible towards intercultural and gender-specific issues (Knuth 2018, p. 129). These described weaknesses are mirrored in all existing studies on the integration of female refugees into the German labour market. Existent literature confirms a low participation rate, a concentration in less attractive segments and part-time jobs, and limited access to measures of labour market integration (Kalkum et al. 2019, pp. 17-18; see also Worbs and Baraulina 2017; Pallmann et al. 2019; Pfeffer-Hoffmann 2018; Fendel 2019). Very recent research shows that the gender differences continue to influence the labour market integration of female and male refugees (Brücker et al. 2019).

Existing discussions are aware of the heterogeneity of migrant groups and the roles of multiple actors which shape labour market integration. Based on their gender, class, and nationality, different migrant groups have access to varying degrees of socioeconomic and political capital, which, in consequence, produces hierarchies among and within them. Not every migrant is equally positioned to make a claim to the labour market in the city where he or she lives. In accordance with this contested nature of space and claim making by migrants who are "differently situated both spatially and temporally" (Cohen and Margalit 2015, p. 669) - we draw on the conceptual framework of "civic stratification" - or "a system of stratified rights" (Morris 2003, p. 79f), to help us to understand the differential access of highly qualified (female) refugees to labour markets and to shed light on the related jungle of volatile regulations. Focusing mainly on the legal differentiations, Morris analysed how "access to employment readily illustrates a stratified system of inclusion and exclusion" in the UK (Morris 2002, p. 411), and thereby moved beyond binary formulations of exclusion and inclusion in the field of migration. This line of thought relies on the idea that migrants are "neither fully included nor fully excluded from the community of citizens and the rights to which they have access" (Mayblin 2016, p. 195). Similarly, Castañeda (2012, p. 71 f.) shows that migrants may gain de facto citizenship status through their involvement in labour markets (formally or informally), by paying taxes, volunteering, or establishing organizations. Furthermore, unlike normative assumptions that depict them primarily as vulnerable and passive recipients of humanitarian measures or welfare benefits, migrants enact agency (Krause and Schmidt 2018, p. 10). This "vulnerability rhetoric" is particularly evident in the course of migrant women who are viewed as "tied movers, being dependent on male family members" (Schwenken 2018, p. 208).

Building on this knowledge, we contribute to existing research by showing that this civic stratification is shaped by formal and top-down practices as well as by more informal and bottom-up strategies. Starting from the observation that since the arrival of a high number of refugees a project-driven support structure, making use of voluntary workers and NGOs, has emerged, informality has seemingly become a practice by which to work around existing limitations and barriers. The stratification of access to the labour markets is highly regulated in theory. In practice it is marked by confusing and contradictory actions. At first sight, the field is characterised by a multiplicity of actors, whilst at second glance, the position of intermediaries is crucial as they have to 
bring together the stratified top-down policies with bottom-up strategies on the spot. A layer of migration-related activities in between the formal and informal fields seemed to have emerged. What has been observed on the global scale as migration industries, controlling and facilitating migration flows, seemed also to be at work in places of destination (Nyberg-Sørensen and Gammeltoft-Hansen 2013). Hidden, somewhat "missing actors" in this layer result to be of utmost relevance for the functioning of the support structures aiming at integrating the newcomers. Among the first authors to point to the roles of such missing actors, was Lipsky (1981), who wrote of street-level bureaucrats, and underlined the importance of intermediary players such as social workers, members of civil society organisations, janitors in accommodation centres, actors in planning agencies, and municipal administrations. Relying on a broad definition of street-level bureaucrats, several studies have focused on how intermediary actors, ranging from government employees, profit-/non-profit organisations, and people to public-private partnerships, interact with migrants and act on their incorporation, sometimes in contradictory ways (Edlins and Larrison 2018; Ambrosini 2018; Alpes and Spire 2014). These works draw our attention to how intermediary actors manage and navigate the differences between official policies and social realities (Ambrosini 2018) given "their proximity to individuals on the frontlines of government" (Edlins and Larrison 2018, p. 3). Hinger et al. (2016, p. 446f) identify this layer as a "zone of negotiation", in which social practises are spelled out in a horizontal and vertical way, and in which different spatialities (bordering, locating, scaling) come together within existing migration regimes.

Despite differences in their formal positions, street level bureaucrats act as intermediary actors between government policy makers and citizens/non-citizens as well as civil servants. They also translate administrative procedures and policies into concrete realities for migrants - they are not only policy takers, but policy shapers who add to a policy assemblage made out of actors, institutions and knowledge, and actively structure the field in a multi-level context (Dörrenbächer and Strik 2018, p. 65). When focusing on the local scale, not only administration professionals, but also the present population (both locals and asylum-seekers), must be integrated into the design of research (Doomernik and Glorius 2016). However, with few exceptions, little is known about gender-differences when looking at the local production of asylum (Mountz 2011), especially when also taking note of implicit patriarchal roles which may also be at work (Kofman 2020, p. 223).

Recent studies on the stratified access of refugees to certain rights draw attention to "regional and local variations" as "access to rights and practices can be different for migrants with the same legal status depending on their location in a nation-state" (ElKayed and Hamann 2018, p. 138), pointing on the spatial dimension of the phenomenon (Doomernik and Glorius 2016; Hinger et al. 2016). In addition, the leeway that cities and regional authorities have in re-interpreting national migration policies has given rise to different governance structures than the ones which national states impose (Mayer 2017). This, in turn, impacts on migrants' capabilities and interactions with other actors within the political opportunity structures of political and economic participation (Koopmans 2004, p. 451 f.; see also Kemp et al. 2015). In this context, refugees' access to labour markets cannot be disconnected from existing local contexts, their participatory dynamics and instruments, and their socio-economic, political and cultural fragmentations. Urban settings with a high degree of inner diversity may work 
differently compared to smaller towns, as they may be more readily able to set up informal support structures due to the already present migrant population.

\section{On methodology}

In accordance with this theoretical and conceptual framework, we concentrate on the interplay between the stratified labour market integration of highly qualified female refugees and the roles that intermediary support structures play out in different localities. As to the case selection, we focus empirically on the cases of cosmopolitan Berlin and the surrounding Land of Brandenburg to shed light on the urban-rural dynamics of the stratified access to gendered labour markets. We consider how regions with a low degree of diversity and a declining population are able to attract and bond highly qualified refugees to be a key question of urban development. In the case of Brandenburg; after re-unification in 1990 many towns lost their native female educated populations to bigger cities all over Germany. When the arrival of large numbers of refugees into the country began in 2015, the share of immigrant population was still below $3 \%$ and thus clearly below the national average of around 10.5\%. The case of Brandenburg represents a situation of double structural discrimination: newcomers arrive in an already disadvantaged regional setting with a low level of diversity and a high degree of xenophobia.

Finally, our empirical findings concentrate on the situation in cosmopolitan Berlin as here the access and willingness of interview partners was considerably higher than in Brandenburg. In our sample, we concentrated on a group of the highly qualified female refugees $^{2}$ (holding an academic degree) within their respective support structures, sometimes set up especially for them in a policy field that has been generated over only the past four years.

Regarding data collection; in addition to the scrutinization of existing literature, we conducted 17 semi-structured interviews with intermediary actors in Berlin and Brandenburg between January and August 2019. These actors included the staff/project leaders and volunteers of civil society organisations designed mainly for refugee women as well as project leaders from universities, employees of job centres and governmentrelated institutions. ${ }^{3}$ The relevant projects of the civil society actors and universities are funded by an array of relevant Federal and Länder Ministries, city governments and the Federal Employment Agency. Some of initiatives are also supported by both donations and the involvement of volunteer groups.

Consistent with the standard techniques of analysing interview data, common themes and patterns were identified and interpreted in accordance with the analytical framework - following a flexible research design adapted to the moving nature of the field of research (Büscher and Urry 2009). Finally, we participated in a series of meetings about female refugees organised by civil society organisations and local authorities in Berlin

\footnotetext{
${ }^{2}$ Our sample involves the support structures that are focused on mainly female refugees from Syria, Iraq, Iran, Afghanistan, Somalia, and Eritrea. Some of the initiatives stated that there were also female refugees and asylum seekers from the Balkans and the former Soviet Union as well as migrant women from other EU countries who have benefited from their support structures.

${ }^{3}$ Our sample included interviews with 8 NGOs in Berlin and 5 government-related institutions, 2 NGOs in Brandenburg and 2 government-related institutions. Further, we included our knowledge from other interviews on migration and integration in Berlin and Brandenburg that took place in 2019 as they could give us insights into special programs.
} 
and Potsdam (=capital of Brandenburg). Through these meetings, which brought together multiple stakeholders ranging from members of civil society organizations, state agencies, and refugees we gained additional insights into their perceptions and concrete strategies about the focus of our research. We did not aim at understanding the process of personal transformation as it is the case in relevant literature on highly skilled female migrants when looking on inclusion (Riano 2015, p. 268ff).

\section{On gendered numbers}

In Germany, and regardless of gender status, the main group of refugees is from Syria, followed by people from Iraq, Iran, Afghanistan, and Eritrea (OECD 2017: Pallmann et al. 2019). Between January and September 2018, 43\% of all asylum applications were made by women; many seeking family reunification. In a representative study on the labour market integration of refugees who arrived between 2013 and 2016, 86\% of female respondents stated that they had planned to work in Germany (Fendel 2019). Such high numbers with regard to expectations of work conflicted with the low level of employment among female refugees actually realised. While the percentage of male refugees engaged in the labour market doubled to 30\% between 2013 and 2017, that of women grew from 2 to $6 \%$. In addition, the study revealed the fairly unequal chances that exist for refugee men and women to access the labour market. Women not only seemed to face even more obstacles to find work than men, they were also less able to accept the work offered. In contrast to men, who mostly came to Germany on their own (57\%), women only exceptionally travelled to Germany on their own (15\%). The study also revealed that refugee women were more likely not to have received any school education ( $17 \%$ vs. $11 \%$ of the men), with $85 \%$ having no formal vocational degree at all (against $83 \%$ of the men). Only $11 \%$ held an academic degree. However, the most striking difference between the men and women who arrived as refugees in Germany was that most men had participated in the labour market before coming to Germany (80\%), while only $40 \%$ of women had done so. Women came with less experience of the workplace. And - this is a crucial finding - they also tend to be older, a factor which, in turn, did not allow for the continuation or the restarting of their studies and education in the place of arrival. Furthermore, many refugee women had children. The general lack of childcare facilities in the places of arrival further narrowed their employment opportunities; this factor had little impact on the labour market integration of the men. Moreover, male refugees more often took part in integration courses. Adding to these imbalances, a mental feature became evident: while female refugees tended to underestimate their knowledge of the German language, men tended to overestimate their knowledge (Kalkum et al. 2019, p. 13). As research shows, gender differences are at stake in both countries of origin and places of arrival (Kofman 2020). The next section investigates the policy contexts of the places of arrival.

\section{The policy context: formal measures of differential inclusion}

Various policy reports as well as our interviewees underline the fact that in recent years German federal policies regarding the labour market integration of refugees and asylum seekers have been reformed (see among others OECD 2017/OECD 2018; Pallmann et al. 2019). In response to the large numbers of arrivals since 2011, as well as a 
consequence of needing to conform to the Reception Conditions Directive of the Common European Asylum System adopted in 2013, Germany facilitated access to certain segments of the labour market for asylum seekers. As a result of legislative changes in 2014, asylum seekers and so-called 'tolerated persons' have been granted the right to work after a three-month waiting period following registration. ${ }^{4}$ In addition, currently recognized refugees and those under subsidiary protection have full access to the labour market. Following the introduction of the Integration Act in August 2016, the priority restriction, which obliges employers to prove that the vacant position cannot be filled by a German or other EU citizen, was suspended in most labour agency districts with low unemployment rates until August 2019 (Konle-Seidl 2017, p. 5).

This differential treatment of different categories of asylum seekers has become more apparent since the 2016 legislative changes. For example, as an administrative category, asylum seekers with an allegedly "good prospect of staying" (mainly people from Syria, Eritrea, Iraq, Iran, and Somalia) are targeted by so-called "early intervention" measures, ${ }^{5}$ such as integration courses, and granted access to mainstream labour market measures. The pilot project, called Early Intervention - Early Labour Market Integration of Asylum Seekers, which ran between 2014 and 2015, mainly targeted skilled asylum seekers in reception centres with a "good prospect to staying" in Germany (KonleSeidl 2017, p. 6f). This project included the "identification of skills, training, further job counselling or job placement[s]". However, asylum seekers from so-called safe countries of origin (Bosnia and Herzegovina, Albania, FYR Macedonia, Montenegro, Kosovo, Serbia, Ghana, and Senegal) are not entitled to work or access the labour market integration support measures. In this context, Germany's asylum and refugee system can be characterized by what Morris once called "a proliferation of statutes of partial membership" (Morris 2003, p. 83), with an opaque stratification of rights with respect to different legal statuses that disregard gender and qualifications. As also underlined by Will (2018), under these circumstances different residency status and the accompanying rights or non-rights are the most significant intervening factors that impact upon stratified access to resources. The resultant hierarchical structure is even more relevant when it comes to the labour market integration of female refugees and asylum seekers. Our interviewees emphasized that there are at least two main categories of male and female refugees and asylum seekers. The so-called "big five" category, consisting of refugees and asylum seekers from Syria, Iran, Iraq, Eritrea, and Somalia, who have access to integration courses and the labour market, and the "safe countries of origin" category which includes women from Afghanistan and provides limited, or no access to either these support measures or the labour market. One of our respondents from a Berlinbased NGO confirmed this and stated that the majority of female asylum seekers who consulted the organization for employment opportunities came from "safe countries" and that legal limitations put them in a disadvantaged position with regard to the labour market. Similarly, as underlined by other interviewed civil society actors, women with tolerated status experienced the stratification of rights and resultant insecurity in

\footnotetext{
${ }^{4}$ People under 'tolerated status' (Duldung) are those whose asylum applications have been rejected but who cannot be deported due to factual, legal, or political reasons.

${ }^{5}$ Under the Integration Act, "early intervention" was underlined as the guiding principle to promote the integration of refugees. Given the long waiting times in the asylum process, the idea behind the early integration measures is to shorten the time of labour market integration of asylum seekers through language and vocational training (Konle-Seidl 2017, p. 6).
} 
a more intense way. They found themselves stuck "in a precarious waiting position, between a constant threat of deportation and occasional incentives for a voluntary return" (Will 2018, p. 182). As a response to these problems, the German government has underlined the need to come up with specific support for refugee women (OECD 2017, p. 59) whilst the Federal Employment Agency established the "Perspectives for Female Refugees" (PerF-W) in 2016; an initiative that includes "vocational language training, site visits at companies and counselling" as well as parallel child-care during the programme (OECD 2017, p. 59). Similarly, the Ministry of Family Affairs, Senior Citizen, Women and Youth funded the programme "Strong in the Job", for which all migrant women and natives with a migrant background were eligible (OECD 2017, p. 59).

In the case of Germany, the level of regulation of the sixteen Länder is of utmost importance for the integration measures adopted in individual localities. While the federal state has the main responsibility to develop the overall framework for labour market integration (ranging from language courses to the legal basis of the labour market access), it is the Länder that formulates and implements policies on housing, health, education, language, vocational training, and labour market integration, especially for asylum seekers. This system incorporates the involvement of a number of different civil society actors.

\section{The reactions of civil society}

In Germany, civil society has collaborated with municipalities and supplemented their work in providing welfare services to migrants for a long time (Mayer 2017, p. 233). There are many religious organizations, non-governmental organizations, volunteers, partially paid helpers, and diaspora associations that support city and Land administrations. Apart from addressing the social and economic needs of migrants, the intermediation actions of these civil society actors involve legal and political advocacy for the rights of migrants. These varied civic actors are also highly active in "encouraging social interactions between [migrants] and Germans" (Neis et al. 2018, pp. 103-104).

Since the 2015 refugee arrivals, Berlin has purposefully upgraded civil society involvement in refugee issues (Toğral Koca 2019). Recently, after the city administration was unable to cope with the many refugees who arrived in 2015 and 2016, the 2016 Master Plan for Integration and Security (MPIS) underlined the importance of civil society, particularly voluntary commitment, in the "reception and integration of refugees" (Master Plan for Integration and Security (MPIS) 2016, pp. 32-35). The MPIS designs structural support for "welcome initiatives" and promotes financial, technical, and administrative support. In 2018, the city of Berlin expanded this policy framework into the Concept for Integration and Participation of Refugees (OECD 2018, p. 12). In line with this framework, various civil society initiatives supporting the labour market integration of female refugees emerged.

Our interview data suggests that especially since 2015, the involvement of both the Land's government and civil society in refugee issues has gained momentum in Brandenburg as well. For example, supported by the Land's government, a new initiative called BEA-Brandenburg (Betriebliche Begleitagentur) was introduced in 2016. As a model project and in cooperation with various stake holders, such as the Employment Agency, the Job Centre, the Chambers, together with civil society organisations, this initiative guides companies in the process of hiring refugees in cooperation with several 
other initiatives open to all migrants (BEA Brandenburg 2019). Similarly, a pilot project for the labour market integration of refugees and asylum seekers was started in 2017. This project aims to connect the latter to mentors and provides funding for their projected business (see OECD 2017, p. 58). Furthermore, in Potsdam, and Cottbus, as well as in smaller cities such as Wildau, and Eberswalde, universities and civil society organizations have become more visible in intermediating refugees' long-term settlement in general, and with regard to labour market integration in particular. Not only did the presence of educational centres such as universities enhance civil society engagement compared to the smaller cities without these centres. It also meant a concrete financial stimulus for the region (see section 5c).

\section{Findings: the gendered pathways of stratified access to the labour market}

The literature on the German case argues that the lower degree of labour market integration of refugee women is to a large extent related to their lower educational levels and lack of previous work experiences compared to male refugees (see Brücker et al. 2014). Yet, both the more recent literature and our fieldwork identified multiple other and often interrelated conditions, including a) the legal setting, b) patriarchal gender roles and missing child care facilities, c) lacking knowledge of the German language and the structure of the country's educational system; d) non-recognition of foreign degrees and work experiences. Furthermore, according to our field work, the majority of civil society initiatives do not develop programmes exclusively for highly qualified female refugees; rather their initiatives target female refugees in general regardless of their individual qualifications. Lastly, we observed, (e) a proliferation of migration-led/ related labour market for non-refugee women and the professionalisation of German female social workers, often with an own migration biography, in this field.

a) The legal setting and gendered immobility

When reflecting on the interplay between labour market integration of refugees and intermediary actors, one of the most important points was existing restrictions on residential mobility (Residenzpflicht). Following a regulation called "constraint of residence", refugees are not allowed to choose where they live - the federal government determines their individual place of residence for a minimum period of three years (Hamann and Karakayali 2016, p. 83). When asylum seekers and refugees do not respect this restriction, they face exclusion from welfare support. Only if they find a job in another district or in certain cases for family reunification reasons, are they allowed to move from their allotted place of residence. ${ }^{6}$ This regionalisation had severe implications in terms of gender. According to the interviewees, female refugees who already face already multiple disadvantages find themselves in places where they cannot enact agency, utilise their skills, access support structures, or find various facilities including language courses and child-care. Here the importance of intermediary civil society organisations and well-connected jobcentres is obvious: immobile refugees need

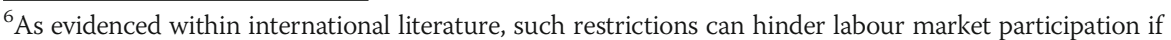
refugees have to live where there are no matching or available work opportunities (Scholten et al. 2017; ElKayed and Hamann 2018; Etzold 2017). Scholten et al. underline that these dispersal policies and the resultant restrictions on residential mobility disregard "economic opportunity structures" (Scholten et al. 2017, p. 10).
} 
information to be brought to them and they are less likely to look after a specialised offer proactively As one of our interviewee from a Brandenburg-based initiative argued, female refugees living in areas with a lack of job opportunities are also far away from support structures and have less chances of becoming part of relevant networks - this scenario was often realised in Brandenburg. This puts the female refugees in a disadvantageous position when it comes to labour market integration compared to those living in the big city of Berlin, where both employment opportunities and support structures are more developed and better aligned to each other. In response to this challenge, civil society initiatives and organizations in Berlin and Brandenburg have started to actively establish more networks and encourage greater cooperation so that they may benefit from their mutual experiences and opportunities. By attending their meetings, we learned that the various actors exchanged their best practices and tried to extend the support structures not only at a regional scale, but also nationwide. Offering a platform for all stakeholders seemed to be a step out of the sectoral silos between the different resorts of the administrations that in many cases still dominates, even in the private sector and among NGOs.

b) Patriarchal gender roles and missing childcare facilities

Our civil society actor interviewees repeatedly underlined that the traditional division of labour within families - seeing the man as the breadwinner and the woman as responsible for childcare and other family responsibilities - contributed to the stratified access of female refugees to the labour market. One expert from a Berlin-based NGO stated: "No matter how they are educated or qualified, this problem still persists in Germany, forcing many female refugees to stay at home and deter their labour market integration." She claimed that refugee men often did not want their wives to gain better qualifications in Germany and that in her view they were jealous when women learned and spoke the language better than they did. Another interviewee, working in an NGO offering language and work-related qualifications in Berlin, argued that they knew female refugees who had given up courses not only because of childcare responsibilities but because of pressure from their husbands. Still, we found some success stories of female refugees who, with the support of civil society organizations, had managed to circumvent these barriers and found jobs.

Organisations/initiatives that exclusively target female refugees with children have emerged. Supported mainly by female volunteers including refugee women, these initiatives not only offered training, language courses, and mentoring but also parallel childcare facilities. For example, one Berlin-based initiative addressed the labour market integration of mothers with a migration background who have completed their studies and wanted to start a new job or continue with their careers. This initiative provided 144 highly qualified female refugees and immigrants with training, coaching, and employment opportunities in cooperation with jobcentres, employers and other civil society initiatives. Of these refugees, $95 \%$ had one or two children, and $23 \%$ of the participants were single mothers. At the end of the project, which took place between 2015 and 2018, 42\% were able to enter the labour market in accordance with their qualifications, $29 \%$ were involved in retraining, and $18 \%$ continued with voluntary work and engagements. Only a minor share of $11 \%$ of the participants did not engage in any 
of the fields. According to the spokesperson of this project, this latter group of highly qualified female refugee could not be employed because of their childcare responsibilities, pressure from their husbands, and demotivation arising from the labour market conditions in Germany. Similar accounts were provided by the spokesperson of a Potsdam-based professional and training programme for the high qualified refugees, who stated that:

"In the beginning of the programme, we received many applications from female refugees. Also, their participation in the programme was high. But recently, both the number of applications and the attendance have been decreasing among the female refugees. Some of them got pregnant during the programmes and they had to quit or have a break. We are not sure about the exact reasons but we can say that family-related reasons seem to be among the main reasons for the decreasing interest in the programme."

Our interviews further revealed the risk that the women might be re-traditionalised by the German institutional system, which, for example, registers husbands as the head of households and results in, for instance, them being the recipient of any allowances granted; putting their wives in positions of dependency.

c) Language and education

All our interviewees underlined that possession of insufficient German language skills was one of the most significant challenges for the labour market integration of female refugees regardless of their qualifications. One of the interviewees offering coaching and mentoring to female refugees stated that

"no matter whether they are qualified and motivated, language is the most important barrier. Some of our programme participants studied and worked in the field of education, political science and office administration in their home countries; but they did not manage to find work even after completing their internship in Germany. Because they could not meet the language requirements."

The interviewees identified different reasons for the language problem. Some of our interviewees said that they considered the state-led courses to be insufficient because of the limitations which they offered to practice the language actively. This holds especially true for female refugees who live in shelters and are largely isolated from German-speaking society. Our interviewees - both from the NGOs and governmentrelated institutions - emphasized that their participation in integration courses and contact with German-speaking people was even further restricted. As the head of a gender-specific programm of a state-related agency told us:

"The female refugees living in shelters are a more disadvantaged group. They have degrees and other qualifications, but they have other priorities; family, children, searching for a flat. Besides, they do not have any privacy in these shelters. They cannot learn the language there, they do not have any life there." 
Recent surveys have also confirmed that female refugees from Syria, Iraq and Eritrea are under-represented in integration courses compared to male refugees and other attendants from EU countries (Worbs and Baraulina 2017, p. 7). In addition, many of those asylum seekers allegedly without a "good prospect to staying" had, at best, limited access to the state-run courses. When made aware of this, some initiatives and NGOs organized free language courses with the support of volunteers.

The civil society organizations interviewed in Berlin argued that the language training opportunities that they offered had already improved the chances of highly qualified female refugees by opening up new spaces for empowerment and networking. Here, language classes offered new spaces of inclusion and encounters between local people and refugees, and thereby contributed positively to the language proficiency of the refugee women. One of our Berlin-based interviewees told us that a refugee woman from Iraq, an engineer, could not find a job for a long-time due to her lack of German proficiency. After she got involved in some of the projects of the NGO, she first started to work as a translator and then as an active supporter of the projects in general. This enabled her to find a job as an engineer at a private company in Berlin. Similarly, a 41-year-old Syrian refugee woman with a background in legal studies and volunteering for civil society organisations, stated that through her active involvement in these organizations she was able to improve her German. She also told us that Berlin's cosmopolitan and migrant-friendly culture motivated her to learn the language and to establish a new life in the city.

Brandenburg towns offered language programmes. For example, at the Technical University of Applied Sciences in Wildau, the Welcome Centre for Refugees offered language courses to support the integration of refugees into degree programmes, financially supported by the German Academic Exchange Service (DAAD). The female refugees who participated in these courses - mainly from Syria, Afghanistan, and Iran were indeed able to enrol in college course even in the field of natural sciences which, in a German context, traditionally gains only a low proportion of female students. This "premediated" continuation between language and academic courses activated new spaces of empowerment for the refugee women. During the period of our research, we observed that since 2015, universities, and universities of applied sciences have taken a leading role in formulating programmes for refugees - in Berlin, but even more in the smaller municipalities in Brandenburg. By doing so, they saw a chance to broaden their internationalization strategies. According to a recent study female refugee participants were less present than their male counterparts: the ratio between the two sexes was about 20 to 80\% in 2018 (Sachverständigenrat deutscher Stiftungen für Integration und Migration (SVR) 2019). In 2016 and 2017 90,000 requests for consultancy from the side of refugees at German universities were registered. Over 25,000 refugees who took part in preparatory courses, around 6000 were thereafter enrolled in Masters courses. The universities soon realized that they had to offer tailored preparation courses for this specific target group. Funding was made available through DAAD for a small number of refugee students. This situation favoured universities in the big cities over those in smaller cities because a majority of migrants live in the bigger cities. Those universities faced with shrinking numbers of students saw potential migrant students as a means by which to mitigate against this loss through (Sachverständigenrat deutscher Stiftungen für Integration und Migration (SVR) 2019, p. 35ff.). While there are no shrinking 
universities in Berlin, in Brandenburg three universities have lost students in the last seven years. Here, the number of foreign students (from 1468 in 2012 to 2542 in 20, 179) counterbalanced the losses of native students (from 12,155 in 2012 to under 10, 000 in 2017) (Sachverständigenrat deutscher Stiftungen für Integration und Migration (SVR) 2019), turning the recruitment of foreign students into a migration-related regeneration strategy for Brandenburg.

d) Non-Recognition of certificates and De-Qualification

Even though refugees and asylum seekers are entitled to apply for recognition of qualifications which they have received from outside of Germany, this is a lengthy and complex bureaucratic process given Germany's strict, yet contradictory, regulations in this field. That is why organizations from the nation-wide Network IQ (Integration through Qualification) in Berlin and Potsdam (Brandenburg) since long offer support and advice to the refugees in their dealings with the complex bureaucratic processes. As stressed by almost all interviewees, refugees faced extra challenges with regard to getting their qualifications recognised because many of them had left behind their documents or lost them when they fled. One of our interviewees from a Berlin-based NGO stated that "those female refugees, who managed to supply their documents, have a better chance of getting a job and advancing their position compared to others lacking their certificates." There appeared to be a significant mismatch between the qualifications and work experiences that refugees had in their countries of origin and the German vocational and labour market system. The interviewee from a Berlin-based project that offered training programmes and consultations for the labour market integration of highly qualified female refugees, stated that especially those with expertise in the fields of medicine, law, and teaching experienced extra obstacles in getting their certificates or previous work experience recognised. She added that many of them had to work either in low-skilled jobs or had to complete additional and lengthy training in order to get their certificates or work experiences accepted. Some female refugees - especially younger and single ones - thus opted to obtain a new degree in Germany. Elder women were not willing to change their fields as the process would require additional commitment and result in further delays before they could enter the labour market, our respondent said. This point was consistent with other interviews in Brandenburg which highlighted that labour market integration is more difficult for older female refugees even when they are highly qualified, know the language, and possess a wide skill set. Another interviewee offering job-search consultation to female refugees in Berlin added that this problem differed between nationalities. She argued that female refugees from regions such as the Balkans and the former Soviet Union experienced minor problems compared to women from the Middle East and African countries as they came from totally different educational settings. These accounts demonstrate how the stratified access of female refugees to the labour market is also conditioned by age and national background.

A major barrier to integration in the labour market is the devaluation of qualifications and previous work experience by employers. Even if degrees are recognized, they are discounted by employers (Verwiebe et al. 2019, p. 1404) Among the projects we visited, one initiative dealt with this issue in an outstanding way by setting up a pilot 
project especially for refugee teachers, financed by the Brandenburg Ministry of Science, Research, and Culture (University of Potsdam). The programme addresses refugees in general who have "successfully completed their teacher training abroad, [and] who have already worked as a teacher in their home country". Here, the goal is to produce "pedagogic professionals" for schools in Brandenburg. In particular, the 18-month program offered "a linguistic and pedagogical qualification, a consultation on occupational perspectives, and it helps [individuals to] overcome structural hurdles when accessing the profession of teaching". This singular program did not explicitly look on gender. In consequence, our interview partner could not specify what the implications in terms of gender were. According to the spokesperson of the initiative,

"The idea of our project is based on if the refugees would not use their qualification, they could lose them. So, we developed this programme in cooperation with the Ministry of Education. In the beginning, it was not clear how to continue with it. Now after completing their trainings, the refugees start their assistant teacher positions mainly at primary schools, where there are severe teacher shortages, especially in the periphery of Brandenburg."

Given the high number of teachers among the female refugees - especially from Syria - as underlined by other interviewees, this programme offers a novel and significant way for the inclusion of female refugees into the labour market.

Devaluation and dequalification were partly counterbalanced by the booming German labour market with its labour shortages in various sectors, as this presented a favourable situation for the labour market participation of refugees and asylum seekers in these years. Refugees with specialisms in the fields of IT, medicine, and different engineering sectors especially benefited, with various civil society initiatives - some of which were supported by the federal state and the Länder - having emerged to support the integration of refugees in these sectors. ${ }^{7}$ One of the initiatives ("Starke Unternehmerinnen für starke Frauen - Eine Initiative für geflüchtete Frauen") ${ }^{8}$ offered not only support for language training and information on the German labour market, but also a variety of mentoring programmes for employers and female refugees - the future employees - together. Furthermore, the initiatives offered IT courses and training in media studies. For example, a Berlin-based computer centre offered a training entitled "Digital Empowerment"- in order enhance the female refugees' labour market integration into the skill-sensitive and technical sectors.

Despite these efforts and the favourable labour market situation, all our interviewees expressed the opinion that highly qualified (female) refugees faced precarious working conditions and were often unable to find jobs that reflected their qualifications. The director of a Berlin-based project that focused on the labour market integration of highly qualified refugees underlined the fact that "it is more difficult for highly qualified female refugees to integrate into the labour market because they do not like to work in low-skilled occupations." For many of them, this signifies downward social mobility rather than a proper integration into the labour market (Etzold 2017, p. 97). One

${ }^{7}$ Such initiatives encompass: a) "Refugee is not a profession" sought to "encourage local businesses to offer job opportunities to migrants" (OECD 2018, p. 157) and to overcome prejudices among the native population. ${ }^{8}$ Meaning: "Strong entrepreneurs for strong women - An initiative for refugee women" 
interview partner, herself a Syrian refugee woman who had previously worked as a professor at a university in Aleppo and was currently volunteering for a civil society organisation, confirmed this statement. She expressed her frustration about the employment opportunities and the stiff competition in German academia. Underlining the difficulties of being a single mother, she told us: "I want to continue my career here and do not want to accept low-skilled jobs, but I have been living here for five years, trying to improve my German. Still, it is very difficult for me to find a position at a German university." Similar findings have been noted in studies on the precarious modes of existence experienced by exiled academics from Turkey in Germany (see Vatansever 2018).

e) Helping the helpers: migration-led regeneration of labour markets

During our empirical research, we became aware that it was especially women working for these initiatives that provided support to refugee women. As one of our interviewees put it: "our concept is by women, for women, and with women." They often work in fixed-term or part-time positions. Some of them had completed their graduate degrees and/or were still working at the universities. For instance, we came across one case in which the innovative idea of combining language education with access to studies at the university of applied science translated into a major project financed by the Land of Brandenburg. We met highly qualified refugee women who were able to assist in local administrations and who became involved in the activities of NGOs as translators and consultants on a learning by doing basis. According to one of the interviewees, the encounter and exchange between them and the refugees helped them to broaden their knowledge. The interviewees identified three inter-related challenges that were likely to hinder the success of their initiatives. First, project funding is mostly limited to a maximum 2 years. According to one interviewee, "as many of these initiatives are developed as pilot projects, the idea is first to test whether they function or not". She added that this uncertainty and short-term approach prevented them from developing sustainable structures to support the labour market integration of refugees in general. Second, many interviewees pointed to the lack of sufficient infrastructure in terms of staff and funding under this short-term approach, and how this hindered their capacity to meet growing interest in their initiatives from amongst female refugees. Third, this short-term perspective places them in a precarious and insecure position in the labour market which is similar to that experienced by the female refugees. As many of the interviewees underlined while conducting one project, they have to look for future funding and project opportunities. We think it is appropriate to speak here of the migration-led emergence of a new labour market segment that contributed to the process of stratified access for the female refugees and has been underestimated so far. Similar to the processes of migration-led regeneration for cities (Hillmann and Pang 2020), migration becomes a driver for broader societal changes.

\section{Conclusion}

Our findings indicate that the labour market integration of (highly qualified) female refugees and asylum seekers takes place in an asylum and refugee system that is strongly marked by the stratification of rights with respect to different legal statuses and gender roles. Our analysis also shows that their positioning in the labour market is shaped by 
multiple and interrelated factors, such as nationality, their place of residence, access to support structures, age, and the transferability of their social capital (e.g. recognition of their certificates and skills).

Our analysis revealed that in response to this situation, multiple actors have developed various types of practices to facilitate better labour market integration. A migration-related institutional infrastructure has emerged helping women of all qualification levels, not only the highly qualified women. In Berlin, and Brandenburg we observed that the cooperation and networks that have been created between the various different state and non-state actors in the field have further developed in recent years. Contesting the stratified access to the labour market, civil society actors in particular play a vital and critical intermediation role between (highly qualified) refugee women and the labour market by offering practical help, language and training programmes, and bureaucratic assistance as well as new spaces of inclusion and encounter. In carrying out these intermediary activities, civil society actors have also started to work in close cooperation with each other and with state agencies such as the Jobcentre, the Foreigners Office and other relevant Ministries. Refugees, including the highly qualified ones, have been integrated into this framework. These findings affirm that "the actual migration governance [can be] quite different from official policies" due to the involvement of various intermediary actors (Ambrosini 2020, p. 4). A central finding of our research is that the arrival of refugees- in particular female refugees - has also created its own field of employment. Within this field all our interviewees were female professionals, either native or with a migration biography themselves.

Our research identified different outcomes in different regional and local contexts. It revealed that Berlin, with its long-standing experience of migration and cosmopolitan character seemed to offer a more fertile ground for both the emergence and practice of support structures as well as the integration of highly qualified refugees into the labour market than the Land Brandenburg. The Berlin-based jobcentre was able to quickly connect with different local stakeholders who had been active in the field over a number of years. In contrast, Brandenburg, with its lower number of migrants and refugees, complemented its relatively weak infrastructure and started working on a more welcoming institutional structure pro-actively. The Land also sought, through so doing, to counterbalance the shrinking numbers of national students enrolled in some of its universities. As our research findings show, Brandenburg has witnessed significant improvements in refugee integration at both institutional and civil society levels. Still, especially in the small towns of the Land Brandenburg, migrants in general face more difficulties and especially those who are highly qualified - as they found themselves far away from institutional settings that normally worked as contact points (universities, civil society initiatives). In contrast, the variety of employment opportunities and the established networks in the different sectors in Berlin continue to attract highly qualified female refugees. Also, the higher degree of present diversity within the city turned out to be of importance for the decision on where to live for the women. According to them it just felt better to be among a culturally mixed environment. So, the lottery of where refugees are allocated to, has strong implications for their possible future labour market integration.

Initially we spoke of a possible trend of "creaming" which favours cosmopolitan cities over small towns, as a consequence of the former offering attractive 
programs for female refugees. Our analysis partly confirmed this tendency, but also showed that their stratified access was further shaped by broader inequalities concerning educational standards in their countries of origin, and through the prescription of traditional gender roles once they arrived in Germany. Even if the few highly qualified women finally could get into contact with the (female!) intermediary actors, their path to integration into the formal labour market remained long and challenging for all concerned.

\section{Authors' contributions}

The author(s) read and approved the final manuscript.

Competing interests

The authors declare that they have no competing interests.

\section{Author details}

${ }^{1}$ Georg-Simmel-Center for Metropolitan Studies, Humboldt-University, Unter den Linden 6, 10117 Berlin, Germany. ${ }^{2}$ Einstein-Fellow, Institute for Urban and Regional Planning, Technische Universität Berlin, Hardenbergstr. 40a, 10623 Berlin, Germany.

Received: 1 May 2020 Accepted: 2 November 2020

Published online: 27 January 2021

\section{References}

Alpes, M. J., \& Spire, A. (2014). Dealing with law in migration control: The powers of street-level bureaucrats at French consulates. Social and Legal Studies, 23(2), 261-274 https://doi.org/10.1177/0964663913510927.

Ambrosini, M. (2018). Irregular immigration in Southern Europe. Actors, dynamics and governance. Cham: Palgrave Macmillan. Ambrosini, M. (2020). The urban governance of asylum as a "battleground": Policies of exclusion and efforts of inclusion in Italian towns. Geographical Review. https://doi.org/10.1080/00167428.2020.1735938.

BEA Brandenburg (2019). Über uns. https://www.bea-brandenburg.de/bea-brandenburg/ueber-uns/. Accessed 27 Apr 2020.

Brücker, H., Croisier, J., Kosyakova, Y., Kröger, H., Pietrantuono, G., Rother, N., \& Schupp, J. (2019). Zweite Welle der IAB-BAMFSOEP-Befragung. Geflüchtete machen Fortschritte bei Sprache und Beschäftigung. In IAB-Kurzbericht http://doku.iab.de/ kurzber/2019/kb0319.pdf, Accessed 16 Oct 2020.

Brücker, H., Liebau, E., Romiti, A., \& Vallizadeh, E. (2014). Arbeitsmarktintegration von Migranten in Deutschland: Anerkannte Abschlüsse und Deutschkenntnisse lohnen sich. In IAB-Kurzbericht http://doku.iab.de/kurzber/2014/kb2114_3.pdf. Accessed 20 Oct 2019

Büscher, M., \& Urry, J. (2009). Mobile methods and the empirical. European Journal of Social Theory, 12(1), 99-116 https://doi. org/10.1177/1368431008099642.

Castañeda, E. (2012). Urban citizenship in New York, Paris, and Barcelona: immigrant organizations and the right to inhabit the city. In M. P. Smith, \& M. Mcquarrie (Eds.), Remaking urban citizenship: organizations, institutions, and the right to the city, (pp. 57-78). New Brunswick and London: Transaction publishers.

Cohen, N., \& Margalit, T. (2015). There are really two cities here': Fragmented urban citizenship. Tel Aviv. International Journal of Urban and Regional Research, 39(4), 666-686 https://doi.org/10.1111/1468-2427.12260.

Doomernik, V., \& Glorius, B. (2016). Refugee migration and local demarcations: New insight into European localities. Journal of Refugee Studies, 29(4), 429-439 https://doi.org/10.1093/jrs/few041.

Dörrenbächer, N., \& Strik, T. (2018). Implementing migration policies. New research puzzles in a Europeanizing context. In A. Weinar, S. Bonjour, \& L. Zhyznomirska (Eds.), The Routledge handbook of the politics of migration in Europe, (pp. 60-70). London: Routledge.

Edlins, M., \& Larrison, J. (2018). Street-level bureaucrats and the governance of unaccompanied migrant children. Public Policy and Administration, 35(4), 403-423 https://doi.org/10.1177/0952076718811438.

El-Kayed, N., \& Hamann, U. (2018). Refugees' access to housing and residency in German cities: Internal border regimes and their local variations. Social Inclusion, 6(1), 135-146 https://doi.org/10.17645/si.v6i1.1334.

Etzold, B. (2017). Capitalising on asylum - The reconfiguration of refugees' access to local fields of labour in Germany. Refugee Review, 3, 82-102.

Fendel, T. (2019). Warum die Jobsuche für geflüchtete frauen so schwer ist. Friedrich-Ebert-Stiftung https://www.fes.de/ arbeitsmarktintegration-gefluechteter-frauen. Accessed 15 Mar 2019.

Hamann, U., \& Karakayali, S. (2016). Practicing Willkommenskultur: Migration and solidarity in Germany. Intersections, 2(4), 6986 https://doi.org/10.17356/ieejsp.v2i4.296.

Hillmann, F., \& Pang, C. L. (2020). Migration-led regeneration: On how cities become more inequal with mixed population flows. Cosmopolitan Civil Societies: an Interdisciplinary Journal, 12(1), i-xi https://epress.lib.uts.edu.au/index.php/mcs/article/ view/7297/7511.

Hillmann, F., \& Wastl-Walter, D. (2011). Geschlechtsspezifische Geographien der migration - Einleitung, Schwerpunktheft der Beiträge zur deutschen Landeskunde. Leipzig: Dt Akademie für Landeskunde.

Hinger, S., Schäfer, P., \& Pott, A. (2016). The local production of asylum. Journal of Refugee Studies, 29(4), 440-463 https://doi. org/10.1093/jrs/few029.

Kalkum, D., Aalders, S., Gundacker, L., \& Brücker, H. (2019). Geflüchtete frauen und Familien. Literaturüberblick zu gender- und familienbezogenen Aspekten der Fluchtmigration und integration. Berlin: BIM.

Kemp, A., Lebuhn, H., \& Rattner, G. (2015). Between neoliberal governance and the right to the city: Participatory politics in Berlin and Tel Aviv. International Journal of Urban and Regional Research, 39(4), 704-725 https:/doi.org/10.1111/1468-2427.12262. 
Knuth, M. (2017). Einwanderung. https://www.netzwerkiq.de/fileadmin/Redaktion/Bilder/Fachstelle_Einwanderung/FE_WP_ FF4_GeflFrauen_2017-04-21_Datei_f\%C3\%BCr_Druck.pdf. Accessed 15 Mar 2019.

Knuth, $\bar{M}$. (2018). Auf alten Wegen zu neuen Zielgruppen - Und wie geflüchtete frauen dabei verpasst warden. In C. PfefferHoffmann (Ed.), Profile der Neueinwanderung 2018: Spezifische Herausforderungen der Arbeitsmarktintegration geflüchteter frauen, Erweiterte und überarbeitete Neuauflage der Ausgabe 2017, (pp. 125-137). Berlin: Mensch und Buch Verlag.

Kofman, E. (2020). Gender and the feminisation of migration. In C. Inglis, W. Li, \& B. Khadria (Eds.), Sage handbook of international migration, (pp. 2016-2231). London: SAGE.

Konle-Seidl, R. (2017). Peer review on 'integration of refugees into the labour Market': Strategies and targeted measures to support integration of refugees into the German labour market. In Host Country Discussion Paper - Germany, DG Employment, Social Affairs and Inclusion http://ec.europa.eu/social/BlobServlet?docld=18666\&langld=en. Accessed 16 Apr 2019.

Koopmans, R. (2004). Migrant mobilisation and political opportunities: Variation among German cities and a comparison with the United Kingdom and the Netherlands. Journal of Ethnic and Migration Studies, 30(3), 449-470 https://doi.org/10.1080/ 13691830410001682034.

Krause, U., \& Schmidt, H. (2018). Vom Opfer zum Akteur? Diskurse über Resilienz von Flüchtlingen und Flüchtlingsschutz. IMISBeiträge, 52, 7-32.

Lipsky, M. (1981). Street-level bureaucracy: Dilemmas of the individual in public services. Publications of Russell Sage Foundation. New York: Russell Sage Foundation.

Master Plan for Integration and Security (MPIS) (2016). Masterplan Integration und Sicherheit. https://www.berlin.de/rbmskzl/ aktuelles/politik-aktuell/2016/meldung.458963.php. Accessed 27 Apr 2020.

Mayblin, L. (2016). Troubling the exclusive privileges of citizenship: Mobile solidarities, asylum seekers, and the right to work. Citizenship Studies, 20(2), 192-207 https://doi.org/10.1080/13621025.2015.1132570.

Mayer, M. (2017). Cities as sites of refuge and resistance. European Urban and Regional Studies, 25(3), 232-249 https://doi.org/ $10.1177 / 0969776417729963$.

Morris, L. (2002). Britain's asylum and immigration regime: The shifting contours of rights. Journal of Ethnic and Migration Studies, 28(3), 409-425 https://doi.org/10.1080/13691830220146527.

Morris, L. (2003). Managing migration: Civic stratification and migrants' rights. The International Migration Review, 37(1), 74-100 https://doi.org/10.1111/j.1747-7379.2003.tb00130.x.

Mountz, A. (2011). Where asylum-seekers wait: Feminist counter-topographies of sites between states. Gender, Place and Culture, 18(3), 381-399 https://doi.org/10.1080/0966369X.2011.566370.

Neis, H. J., Meier, B., \& Furukawazono, T. (2018). Welcome City: Refugees in three German cities. Urban Planning, 3(4), 101-115 https://doi.org/10.17645/up.v3i4.1668.

Nyberg-Sørensen, N., \& Gammeltoft-Hansen, T. (2013). The migration industry and the commercialization of international migration. London: Routledge.

OECD (2017). Finding their Way: Labour market integration of refugees in Germany. https://www.oecd.org/els/mig/Findingtheir-Way-Germany.pdf. Accessed 20 Aug 2019.

OECD (2018). Working Together for Local Integration of Migrants and Refugees in Berlin. http://www.oecd.org/publications/ working-together-for-local-integration-of-migrants-and-refugees-in-berlin-9789264305236-en.htm. Accessed 20 Aug 2019.

Pallmann, I., Ziegler, J., and Pfeffer-Hoffmann, C. (2019). Refugee Women as a Target Group of Labour Market Policies. https:// www.netzwerkiq.de/fileadmin/Redaktion/Downloads/Fachstelle_Einwanderung/Publikationen_2019/FE_Refugee_ Women_as_a_Target_Group_of_Labour_Market_Policies.pdf. Accessed September 2019.

Pfeffer-Hoffmann, C. (2018). Profile der Neueinwanderung 2018: Spezifische Herausforderungen der Arbeitsmarktintegration geflüchteter Frauen. https://www.netzwerk-iq.de/fileadmin/Redaktion/Downloads/Fachstelle_Einwanderung/ Publikationen_2018/FE_Kompakt_11_2018_Statistik.pdf. Accessed 27 April 2020.

Riano, Y. (2015). Participatory Minga workshops with highly skilled migrant women: Enhancing spaces of inclusion. In Qualitative research, 16.3, (pp. 267-279).

Sachverständigenrat deutscher Stiftungen für Integration und Migration (SVR) (2019). Dem demografischen Wandel entgegen: Wie schrumpfende Hochschulstandorte internationale Studierende gewinnen und halten. Berlin: Studie des SVRForschungsbereichs.

Scholten, P., Baggerman, F., Dellouche, L., Kampen, V., Wolf, J., \& Ypma, R. (2017). Policy innovation in refugee integration? A comparative analysis of innovative policy strategies toward refugee integration in Europe. The Netherlands: EMDI-Erasmus University Rotterdam.

Schwenken, H. (2018). Intersectional migration regime analysis: Explaining gender-selective labor emigration regulations. In A. Pott, C. Rass, \& F. Wolff (Eds.), Was ist ein Migrationsregime?: What is a migration regime? (pp. 207-224). Wiesbaden: Springer VS.

Toğral Koca, B. (2019). Local bordering practices, refugees, and civil society: The case of Berlin. Geographical Review, 109(4), 544-561 https://doi.org/10.1111/gere.12351.

Vatansever, A. (2018). Academic nomads. The changing conception of academic work under precarious conditions. Cambio, 8(15), 153-165 https://doi.org/10.13128/cambio-22537.

Verwiebe, R., Kittel, B., Dellinger, F., Liebhart, C., Schiestl, D., Haindorfer, R., \& Liedl, B. (2019). Finding your way into employment against all odds? Successful job search of refugees in Austria. Journal of Ethnic and Migration Studies, 45(9), 1401-1418 https://doi.org/10.1080/1369183X.2018.1552826.

Will, A. K. (2018). On "genuine" and "illegitimate" refugees: New boundaries drawn by discriminatory legislation and practice in the field of humanitarian reception in Germany. Social Inclusion, 6(3), 172-189 https://doi.org/10.17645/si.v6i3.1506,

Worbs, S., \& Baraulina, T. (2017). Female refugees in Germany: Language, education and employment. (BAMFBrief analysis, 12017). Nürnberg: Bundesamt für Migration und Flüchtlinge (BAMF) Forschungszentrum Migration, Integration und Asyl (FZ) https://nbn-resolving.org/urn:nbn:de:0168-ssoar-67555-1.

\section{Publisher's Note}

Springer Nature remains neutral with regard to jurisdictional claims in published maps and institutional affiliations. 